\author{
KATARZYNA KoWALSKA \\ Uniwersytet Pedagogiczny w Krakowie, Polska \\ Pedagogical University of Cracow, Poland
}

\title{
Upowszechnianie praktyk CSR w ramach współpracy międzynarodowych korporacii z lokalnymi firmami kraju przyjmującego
}

\section{Dissemination of CSR Practices within the Framework of Cooperation Between International Corporations and Local Companies of the Host Country}

\begin{abstract}
Streszczenie: W dobie globalizacji, w której wiele firm posiada rozbudowane łańcuchy dostaw, współpraca z dostawcami jest kluczowym obszarem ograniczenia ryzyka reputacyjnego i polem do realizacji praktyk CSR. Ograniczenie ryzyka refutacyjnego oznacza konieczność prowadzenia zintegrowanych działań w całym łańcuchu dostaw oraz budowania trwałych relacji z kooperantami w oparciu o normy i standardy CSR obowiązujące obie strony transakcji. Współpraca międzynarodowych korporacji z lokalnymi przedsiębiorstwami wywołuje procesy dostosowawcze wśród dostawców (również w obszarze CSR); oznacza redystrybucję umiejętności i wiedzy do zleceniobiorców, co w praktyce pozytywnie wpływa na pozycję konkurencyjną analizowanych grup podmiotów. W artykule wykorzystano metodę opisową. Ma on na celu scharakteryzowanie współpracy międzynarodowych korporacji z lokalnymi firmami w kontekście upowszechniania praktyk CSR w łańcuchu dostaw. Przedmiotem artykułu jest współpraca międzynarodowych korporacji z firmami kraju goszczącego w ramach tzw. powiązań do tyłu (backward linkages), ze szczególnym uwzględnieniem praktyk CSR.
\end{abstract}

\begin{abstract}
In the era of globalization, where many companies have extensive supply chains, cooperation with suppliers is a key area for limiting reputational risk, as well as a field for implementing CSR practices. Reducing reputational risk means the need of conducting integrated operations within the supply chain; building permanent relationships with cooperators based on CSR standards and standards applicable to both parties of the transaction. The cooperation of international corporations with local businesses evokes adaptation processes among suppliers (also in the area of CSR); it also means redistribution of skills and knowledge towards contractors, which in practice has a positive impact on the competitive position of the analyzed groups of entities. In the article, a descriptive method was used. The purpose of this article is to characterize the cooperation of international corporations with local companies in the context of dissemination of CSR practices in the supply chain. The subject of the article is cooperation of international corporations with companies of the host country within the so-called backward linkages; with particular emphasis on CSR practices.
\end{abstract}

Słowa kluczowe: CSR; konkurencja; korporacja; współpraca Keywords: competition; cooperation; corporation; CSR 
Otrzymano: 5 stycznia 2018

Received: 5 January 2018

Zaakceptowano: 19 maja 2018

Accepted: 19 May 2018

Sugerowana cytacja / Suggested citation:

Kowalska, K. (2018). Upowszechnianie praktyk CSR w ramach współpracy międzynarodowych korporacji z lokalnymi firmami kraju przyjmującego. Prace Komisji Geografii Przemysłu Polskiego Towarzystwa Geograficznego, 32(2), 142-151. https://doi.org/10.24917/20801653.322.9

\section{WSTĘP}

W dzisiejszych uwarunkowaniach rynkowych wiele okoliczności sprzyja tworzeniu różnego rodzaju interakcji przedsiębiorstw na rynku. Kluczowe znaczenie ma tutaj pogłębiający się proces internacjonalizacji przedsiębiorstw i szereg korzyści, jakie oferują międzynarodowym korporacjom kraje je przyjmujące.

Silna presja konkurencji i rosnąca świadomość społeczna sprawiają, że w warunkach złożonych i wydłużonych sieci powiązań budowanie odpowiedniej reputacji przedsiębiorstwa staje się kluczowym elementem strategii rozwoju firmy. W praktyce oznacza to, że podmioty gospodarcze muszą określić zobowiązania za czyny własne i cudze. Zobowiązania te dotyczą aspektów ekonomicznych, społecznych i środowiskowych i odnoszą się do różnych grup interesariuszy danego przedsiębiorstwa. Na wielu rynkach (szczególnie wysoko rozwiniętych) długoterminowy rozwój przedsiębiorstwa zależy właśnie od umiejętności spełniania szeroko rozumianych oczekiwań społecznych.

Ukierunkowanie na rozwój przedsiębiorstwa wymaga zatem odpowiedniego spojrzenia na własny łańcuch dostaw, szczególnie zaś na proces budowania relacji z dostawcami.

W artykule wykorzystano metodę opisową. Ma on na celu scharakteryzowanie współpracy międzynarodowych korporacji z lokalnymi firmami dotyczącej upowszechniania praktyk CSR w łańcuchu dostaw. Przedmiotem artykułu jest współpraca międzynarodowych korporacji z firmami kraju goszczącego w ramach tzw. powiązań do tyłu (backward linkages), ze szczególnym uwzględnieniem praktyk CSR.

\section{UWARUNKOWANIA WSPÓŁPRACY MIĘDZYNARODOWYCH KORPORACJI Z LOKALNYMI PRZEDSIĘBIORSTWAMI}

Pogłębiający się proces umiędzynarodawiania współczesnej gospodarki światowej wywołuje wzrost liczby i intensywności powiązań między przedsiębiorstwami. Kluczową rolę w przypadku tych relacji odgrywają korporacje międzynarodowe, które dokonują ekspansji na rynki zagraniczne, zmieniają realia konkurencji, wyznaczają nowe trendy i standardy działania (Kowalska, 2012).

Decyzja przedsiębiorstwa dotycząca zagranicznej ekspansji wiąże się z wyborem sposobu wejścia na określony rynek, co ma wpływ na jego wyniki finansowe, pozycję konkurencyjną i możliwości nawiązywania współpracy z podmiotami kraju przyjmującego.

Formy (sposoby) internacjonalizacji przedsiębiorstw są pochodną stopnia trudności wejścia na rynki zewnętrzne, wielkości danej firmy, motywów umiędzynarodowienia, 
dystansu psychicznego między krajem macierzystym a przyjmującym oraz doświadczenia w działalności międzynarodowej. Najczęstszą i najbardziej zaawansowaną formą wejścia międzynarodowych korporacji na zagraniczne rynki jest rozwój organiczny w postaci zagranicznych inwestycji bezpośrednich (ZIB).

Omawiana forma zagranicznej ekspansji charakteryzuje się przede wszystkim przyjęciem pełnego ryzyka działalności, samodzielnością w ponoszeniu nakładów finansowych, jak również pełną swobodą w prowadzeniu polityki rozwoju na rynkach zagranicznych, w tym wyboru partnerów i obszarów współpracy na rynkach goszczących (Kochaniec, 2002).

Dla poruszonego w artykule tematu (współpraca międzynarodowych korporacji z lokalnymi firmami) istotne znaczenie mają również motywy podejmowania i rozszerzania przez przedsiębiorstwa działalności międzynarodowej.

W literaturze przedmiotu podkreśla się, że omawiana ekspansja dokonuje się pod wpływem czterech zasadniczych grup motywów, mianowicie: rynkowych, kosztowych, związanych z pozyskiwaniem strategicznych zasobów i motywów efektywnościowych (Przybylska, 2001). Motywy te stanowią podstawowe kryteria wyboru miejsca lokalizacji przedsiębiorstw za granicą, a ich rola i znaczenie zależy w dużej mierze od rodzaju działalności i obranej strategii rozwoju przez dane przedsiębiorstwo.

Dla przykładu, dla korporacji handlowych kluczowe znaczenie ma motyw rynkowy (potrzeba pozyskania dodatkowych rynków zbytu, wejścia na zagraniczne rynki), natomiast w przedsiębiorstwch produkcyjnych do głosu dochodzą przede wszystkim motywy kosztowe i związane z pozyskaniem strategicznych zasobów.

Motywem internacjonalizacji, o którym dyskutuje się najbardziej, jest motyw poszukiwania strategicznych aktywów. Dostęp do zasobów i umiejętności innych firm (m.in. do wiedzy o rynku, znajomości zachowań i preferencji klientów, zdolności do utrzymania z nimi bliskich kontaktów) pozwala bowiem na generowanie nowych źródeł przewagi konkurencyjnej; dostęp ten pozwala wesprzeć atuty przedsiębiorstwa i skoncentrować się na kluczowych obszarach jego działalności.

W literaturze przedmiotu wskazuje się, że specyficznym zasobem mogą być również relacje (wzajemne powiązania), które łączą daną firmę z innymi podmiotami (Przybylska, 2001). A. Sulejewicz w tym kontekście podkreśla, że aktywa te stanowią podstawę strategicznej rywalizacji i w praktyce generują quasi-rentę organizacyjną (Sulejewicz, 1997).

W praktyce przedsiębiorstwa, chcąc sprostać współczesnej konkurencji, zmuszone są poszukiwać optymalnych rozwiązań; integrują poszczególne korzyści: rynkowe, kosztowe i zasobowe.

Jak już wcześniej zaznaczono, internacjonalizacja międzynarodowych korporacji stwarza podstawę do powstania licznych interakcji (różnych form współpracy) tych podmiotów z firmami kraju je przyjmującego. Współpraca ta jest dobrowolna i nastawiona na osiąganie wspólnych korzyści. Może mieć charakter kapitałowy (umowy franchisingowe, sprzedaż licencji i kontrakty menedżerskie) lub niekapitałowy (joint venture, alianse strategiczne).

Współpraca na linii korporacje-lokalne przedsiębiorstwa w praktyce może dotyczyć zaopatrzenia, sprzedaży, współpracy z przedsiębiorstwami prowadzącymi konkurencyjną działalność (Burt, 2001). Tym obszarom odpowiadają określenia: powiązań do tyłu (backward linkages), powiązań do przodu (forward linkages) i powiązań poziomych (horizontal linkages). 
Powiązania do tyłu występują, kiedy korporacje zaopatrują się w dobra i usługi w lokalnych firmach kraju goszczącego, natomiast powiązania do przodu - gdy zagraniczne firmy sprzedają swoje produkty lokalnym przedsiębiorstwom (Przybylska, 2010). Z kolei powiązania horyzontalne obejmują współpracę zagranicznych filii i oddziałów z firmami konkurencyjnymi w kraju goszczącym (Przybylska, 2010).

Z punktu widzenia tematu poruszonego $\mathrm{w}$ artykule kluczowe znaczenie mają powiązania do tyłu, czyli z dostawcami. Udział lokalnych firm we współpracy z korporacjami najczęściej przybiera formę podwykonawstwa, która polega na zleceniu wykonania produktu lub jego części innemu niezależnemu przedsiębiorstwu, zgodnie z zamówieniami i parametrami określanymi przez firmę oferującą taki kontrakt (Taymaz, Kilıcaslan, 2005).

Podwykonawstwo można opisać jako szczególną formę outsourcingu, która obejmuje bezpośrednie kontakty oraz wymianę wiedzy i informacji między obiema stronami kontraktu (Taymaz, Kilıcaslan, 2005).

Popularność powiązań przedsiębiorstw $\mathrm{w}$ ramach outsourcingu wynika z licznych korzyści, jakie mogą wynikać z kontraktu zarówno dla klienta, jak i usługodawcy systemu. Przede wszystkim, z powodu rosnącej konkurencji i niepewności na rynkach międzynarodowych, przedsiębiorstwa skupiają się na kluczowych obszarach swojej działalności (core business), co wywołuje silny popyt na usługi outsourcingowe.

Zdaniem przedstawicieli czołowych światowych firm doradczych korzyści projektów outsorcingowych sprowadzają się przede wszystkim do restrukturyzacji kosztów, jak również do zwiększenia elastyczności i potencjału organizacji (Meronk, Bielewicz, 2009).

Outsorcing pozwala na oszczędność przynajmniej części środków inwestowanych w długotrwałe działania służące budowaniu potrzebnych kompetencji i zmienia je na znacznie mniejsze opłaty stałe (Meronk, Bielewicz, 2009).

Outsourcing to również ważne narzędzie ekspansji przedsiębiorstw na rynki zagraniczne. W dobie silnej internacjonalizacji przedsiębiorstw okazuje się być skutecznym i szybkim sposobem wejścia na rynki zewnętrze, bez konieczności budowania złożonych i kosztownych kompetencji (Meronk, Bielewicz, 2009).

W literaturze przedmiotu podkreśla się również, że w dłuższej perspektywie outsourcing jest sposobem pozyskania niemal nieograniczonych światowych zasobów siły roboczej, która dzięki lokalizacji w różnych strefach czasowych może realizować zlecenia przez całą dobę (Prahald, Krishan, 2008), jest również kanałem transferu technologii.

Zewnętrzni dostawcy, w ramach omawianych projektów, zapewniają często niezbędną elastyczność, ciągłość działania i szybkość relacji na zapotrzebowanie klientów, co przekłada się na możliwości kreowania dla klienta wartości dodanej (Meronk, Bielewicz, 2009).

Rosnące znaczenie omawianych powiązań wynika również ze zmian, jakie zachodzą w projektowaniu technologii powodujących konieczność częstych modyfikacji czynników wytwórczych i produktów (Przybylska, 2001).

Natomiast korzyści dla lokalnych przedsiębiorstw płynące ze współpracy z międzynarodowymi korporacjami to przede wszystkim (Przybylska, 2010):

- poprawa kondycji finansowej,

- możliwość zwiększenia rynków zbytu,

- dostęp do nowoczesnej technologii, 
- zmiana sposobu myślenia i działania właścicieli i menedżerów małych firm po wejściu do międzynarodowej sieci,

- możliwość pozyskiwania cennych informacji i doświadczeń, które niwelują bariery rozwoju charakterystyczne dla małych i średnich przedsiębiorstw,

- wzrost wiarygodności przedsiębiorstwa na rynku krajowym i rynkach zagranicznych,

- procesy dostosowawcze.

W literaturze przedmiotu wskazuje się również na ryzyko wystąpienia po stronie lokalnych firm kosztów współpracy z międzynarodowymi korporacjami. Korporacje posiadające przewagę transakcyjną mogą tworzyć coraz większy popyt na określone struktury organizacyjne i zarządcze, co skutkować może coraz większymi barierami dla lokalnych producentów (Tylec, 2010).

Często podkreśla się także, że poważnym zagrożeniem może być sprowadzenie lokalnych podmiotów do pełnienia funkcji dostawcy prostych czynników produkcji i niewyspecjalizowanych usług, cechujących się niską wartością dodaną (Tylec, 2010). Innym zagrożeniem, regularnie odnotowywanym na polskim rynku, tym razem wśród korporacji handlowych, są liczne praktyki nadużywania silnej pozycji w stosunku do kooperantów w postaci narzucania warunków umów i długich terminów płatności oraz pobierania nieuzasadnionych opłat marketingowych (NIK, 2002).

\section{PRAKTYKI CSR W RAMACH WSPÓŁPRACY KORPORACJI Z LOKALNYMI FIRMAMI}

Rozwój współpracy międzynarodowych korporacji z lokalnymi firmami kraju przyjmującego wymusza od tych drugich, dysponujących słabszą pozycją i mniejszym doświadczeniem rynkowym, dostosowanie się do jakościowych i ilościowych warunków współpracy. Można mówić o różnych obszarach tych ustaleń i ich pozytywnych oraz negatywnych skutkach. Coraz częściej jednak, dla poprawy kondycji rynkowej przedsiębiorstw lokalnych, istotne znaczenie mają wymogi (standardy, normy) w zakresie społecznej odpowiedzialności przedsiębiorstw (CSR - Corporate Social Responsibility).

W literaturze przedmiotu występuje wiele definicji CSR. Pojęcie to wciąż ewoluuje. Można jednak zaproponować definicję tego terminu, ujmując ją jako świadome działanie podjęte w danej organizacji, inspirowane rezultatami dialogu społecznego i nakierowane na tworzenie społecznie istotnych wartości odpowiadających oczekiwaniom interesariuszy (Rojek-Nowosielska, 2017: 82).

Kluczową kwestią dla wdrażania CSR w organizacji jest odpowiedzialne zarządzanie łańcuchem dostaw. Jest to praktyczne przełożenie omawianej koncepcji na działalność przedsiębiorstwa. Obejmuje ono wszelkich kontrahentów dostarczających produkty i usługi niezbędne firmie do zaoferowania finalnego towaru na rynku i dotyczy trzech podstawowych obszarów:

- ekonomicznego - m.in. uczciwe warunki kontraktów, terminowe płacenie należności, niewykorzystywanie przewagi ekonomicznej do negocjowania nieadekwatnych cen i warunków umów, zapobieganie korupcji, co przekłada się na relacje firm z ich dostawcami,

- społecznego - m.in. przestrzeganie prawa pracy i praw człowieka, godziwe wynagrodzenia dla pracowników, przestrzeganie ustalonych godzin pracy oraz bezpieczeństwo w miejscu pracy i relacje kształtowane z lokalną społecznością, 
- środowiskowego - m.in. oddziaływanie na środowisko, co należy odnieść do całego cyklu życia produktu - od jego projektowania po utylizację, uwzględniając również transport materiałów i wykorzystanie surowców; nie bez znaczenia jest tutaj również efektywność energetyczna, możliwość ponownego przetworzenia materiałów. Eksperci w zakresie CSR zgodnie podkreślają, że uwzględnianie w decyzjach szeroko rozumianych skutków oddziaływania firmy na otoczenie wynika z konieczności dostosowania się do realiów konkurencji na rynku. Twierdzą, że samo kreowanie wartości ekonomicznej w biznesie nie stwarza firmie możliwości osiągania dochodu pozwalającego na utrzymanie się na rynku (Ćwik, 2011). Coraz większe znaczenie ma minimalizowanie ryzyka reputacyjnego w biznesie.

Reputacja to subiektywna i zbiorowa ocena tego, czy organizacja jest wiarygodna i godna zaufania (Szwajca, 2016: 88). Zaufanie stanowi podstawę reputacji, natomiast reputacja wpływa na budowanie i wzmacnianie zaufania różnych grup interesariuszy (pracowników, kontrahentów, klientów, instytucji rządowych i pozarządowych, społeczności).

Dla przykładu, zaufanie pomiędzy partnerami w sieciach dostaw powoduje wiele pozytywnych skutków: zmniejsza asymetrię informacji, utrwala współpracę, zmniejsza koszty transakcyjne, stanowi wyróżnik przy ubieganiu się o różnego rodzaju kontrakty (również na rynku międzynarodowym). Podobną zależność można zauważyć pomiędzy reputacją a poziomem zaufania klienta oraz jego identyfikacją z firmą, co przekłada się na intencje zakupów oraz akceptację przez klientów wyższej ceny (Szwajca, 2016).

Biorąc pod uwagę fakt, że współczesne łańcuchy dostaw globalnych firm są bardzo rozbudowane, wdrażanie odpowiedzialnego łańcucha dostaw wymaga ścisłej współpracy z kontrahentami (dostawcami) w oparciu o wytyczne i kodeksy postępowania, podlegające zewnętrznym audytom.

Wytyczne dla dostawców i ich kontrola wydają się być - z powodu rosnącego znaczenia powiązań biznesowych - kluczowe dla długoterminowego wzrostu wartości przedsiębiorstwa. Minimalizowanie ryzyka reputacyjnego wymaga bowiem nadzoru nad działaniami wewnątrz własnej organizacji, jak również kontrolowania usług świadczonych przez firmy zewnętrzne. Problem odpowiedzialności firm m.in. w relacjach outsourcingowych to konieczność określenia przez podmioty gospodarcze społecznych zobowiązań za czyny własne i cudze.

Powyższa kwestia jest kluczowa, bo - jak wynika z badań przeprowadzonych w Polsce - zdecydowana większość przedsiębiorstw kontroluje pod względem CSR jedynie dostawców pierwszego rzędu, a część z nich w ogóle nie monitoruje omawianych aspektów w dalszej części łańcucha dostaw (Ćwik, 2011).

W odpowiedzi na potrzebę rynku i biznesu opracowane zostały międzynarodowe, funkcjonalne standardy CSR. Standardy te służą zarządzaniu społeczną odpowiedzialnością, pozwalają identyfikować społeczne i środowiskowe ryzyka. Odnoszą się do poziomu podjęcia zobowiązania realizacji zasad CSR, co powinno stanowić podstawę budowania przez firmę wartości w długim okresie (Makuch, 2011). W szczególności dotyczy to kodeksów zawierających uniwersalne zasady, czyli Wytyczne OECD, 10 zasad Global Compact, ISO 26000, która jest swego rodzaju podsumowaniem teorii i praktyki CSR (Makuch, 2011).

W kontekście podjętego tematu warto również wskazać na GRI - wytyczne do raportowania CSR. Tworzą one ogólne ramy dla raportowania wymienionych wyżej obszarów zrównoważonego łańcucha dostaw (Makuch, 2011). Raportowanie danych 
pozafinansowych jest kluczowym narzędziem CSR, pozwala bowiem na kompleksową (wieloaspektową) ocenę działalności przedsiębiorstwa.

Na gruncie polskim próbę odniesienia najistotniejszych międzynarodowych standardów CSR do realiów rodzimego rynku stanowi projekt „Koalicja na rzecz odpowiedzialnego biznesu", realizowany przez Pracodawców RP (Makuch, 2011).

$\mathrm{Na}$ liście największych korporacji prezentowanych co roku przez Word Investment Report praktycznie nie ma takich, które nie deklarowałyby wprowadzenia zasad społecznej odpowiedzialności do swoich strategii.

Takie praktyki od kilku lat realizuje np. firma H\&M, poprzez stosowanie Kodeksu Postępowania (Code of Conduct), który wyznacza społeczne i środowiskowe standardy dla dostawców. Firma zapewnia, że zobowiązuje każdego dostawcę do podpisania Kodeksu Postępowania przed rozpoczęciem procesu produkcji. Dodatkowo firma prowadzi program audytu (Full Audit Program - FAP), któremu podlegają jej partnerzy.

Powyższe praktyki, choć pozytywnie ukierunkowane, okazują się być niewystarczające. Nierzadko słyszymy o braku konsekwencji pomiędzy tym, co omawiane firmy deklarują, a tym, co faktycznie realizują w zakresie odpowiedzialnego biznesu. Koncernowi H\&M (a raczej fabrykom produkującym dla szwedzkiego koncernu) udowodniono m.in. wykorzystywanie bardzo szkodliwej dla zdrowia i środowiska metody piaskowania do wybielania ubrań (Fundacja Centrum CSR, 2013).

Inny przykład dotyczy sieci detalicznej Wal-Mart. W 2012 roku fundusz emerytalny Algemeen Burgerlijk Pensioenfonds (ABP), zarządzający aktywami w wysokości 300 mld dol., zdecydował o wycofaniu się z inwestycji Wal-Mart i umieszczeniu firmy na tzw. czarnej liście (CSRinfo, 2012). Przyczyną takiej sytuacji były nagminne nadużycia koncernu w zakresie praw pracowniczych, kwestii środowiskowych i brak wystarczających postępów, by zmienić tę sytuację (CSRinfo, 2012).

Praktyki CSR międzynarodowych korporacji mają często charakter wybiórczy, sektorowy i marketingowy, uzależniony od stadium rozwoju rynku - realiów politycznych z nim związanych i poziomem ryzyka reputacyjnego na danym rynku.

Społeczna odpowiedzialność biznesu w Polsce jest koncepcją wyraźnie rozwijającą się. Widać mniejsze zaangażowanie sektora małych i średnich przedsiębiorstw (MŚP) w stosunku do międzynarodowych korporacji. Wynika to w dużej mierze z braku wiedzy MŚP, jak również z niedostatecznej ilości źródeł, które opisywałyby koncepcję CSR w sposób przejrzysty i dostosowany do realiów funkcjonowania małych i średnich przedsiębiorstw (CSRinfo, 2012); a także z ich ograniczeń finansowych (Rojek-Nowosielska, 2017).

Rozwój tej koncepcji na polskim rynku w dużej mierze odbywa się za sprawą korporacji, które - wchodząc na nasz rynek - podejmują współpracę z rodzimymi przedsiębiorstwami. Jako podmioty silniejsze rynkowo, o dużo większym doświadczeniu rynkowym, narzucają krajowym firmom przyjęte normy i standardy działania, monitorują ich realizacje, szkolą dostawców w przedmiotowym zakresie. Z drugiej strony realizacja zleconych przez korporację zadań oznacza szereg istotnych efektów, tzw. efektów zamierzonych (np. unowocześnienie produkcji, by sprostać określonym warunkom jakościowym) i niezamierzonych.

Jeżeli chodzi o efekty niezamierzone, wyróżnić można produkcyjne efekty spillovers oraz rynkowe efekty spillovers (Tylec, 2010). Produkcyjne spillovers przejawiają się we wzroście konkurencyjności przedsiębiorstw lokalnych i/lub dalszej redystrybucji 
wiedzy i postaw do partnerów poprzez podwykonawstwo lub wystąpienie efektu demonstracji (Tylec, 2010). Natomiast rynkowe spillovers mają miejsce wówczas, gdy relacje kooperacyjne między korporacjami a lokalnymi firmami skutkują większym dostępem do rynków zagranicznych (Tylec, 2010).

Pamiętać jednak należy, że - podobnie jak w przypadku technologii - sam transfer norm i standardów współpracy w zakresie CSR nie warunkuje w długim okresie czasu poprawy pozycji przedsiębiorstwa na rynku. Kluczowe znaczenie dla lokalnych firm uczestniczących w omawianych układach biznesowych ma ich zdolność do absorpcji wiedzy i skłonność do uczenia się.

Nabycie nowych umiejętności i wiedzy w zakresie CSR owocuje wzrostem innowacyjności. CSR stymuluje tzw. zrównoważone innowacje, nowy sposób myślenia, bardziej efektywny ekonomicznie, społecznie i ekologicznie. Chodzi o nowe rozwiązania odpowiadające potrzebom rynku - przeciętnego konsumenta, jak również pozostałych interesariuszy, od których zależy rozwój firmy w dłuższej perspektywie.

Na przykładzie polskiej firmy Mega, produkującej meble pod markami dużych firm, można wskazać, jakiego rodzaju zobowiązania wiążą się z byciem dostawcą dla korporacji. Świadczenie tego rodzaju usług zobowiązuje spółkę do ciągłego usprawniania produkcji (według wyznaczonych standardów i działań wspomagających); co roku odbiorcy produktów Mega audytują działalność przedsiębiorstwa pod kątem zrównoważonej i uczciwej (społecznie i ekologicznie) produkcji. Spółka w ramach współpracy realizuje różne działania w zakresie CSR, a potwierdzeniem tego jest m.in. posiadanie certyfikatu FSC (Forest Steward Council), który zaświadcza wykorzystanie w produkcji materiałów drzewnych pochodzących z dobrze zarządzanych lasów (PARP, 2015).

Innowacja $\mathrm{w}$ firmie Mega wiąże się z optymalizacją procesu automatycznego szlifowania, w celu ograniczenia energochłonności procesu, zmniejszenia ilości odpadów oraz rozszerzenia oferty o produkty certyfikowane FSC Reclaimed Wood (PARP, 2015). Efektem takiego podejścia jest ograniczenie kosztów działalności, budowanie pozytywnego wizerunku firmy, zapewnienie jej trwałej współpracy ze zleceniodawcą, a ostatecznie poprawa jej pozycji konkurencyjnej na rynku.

Na podstawie powyższego przykładu widać, że orientacja na CSR nie jest jedynie domeną korporacji wyposażonych w odpowiedni kapitał i zaplecze pracowników. Lokalne firmy, chcąc współpracować z zagranicznymi przedsiębiorstwami, dostosowują się do warunków współpracy i dokonują istotnych zmian w biznesie, zgodnych z aktualnymi trendami i potrzebą optymalizacji kosztów.

Zmiana sposobu myślenia i działania właścicieli i menedżerów małych firm jest funkcją wiedzy i doświadczenia korzyści związanych z realizacją polityki CSR.

\section{ZAKOŃCZENIE}

W dobie globalizacji, w której wiele firm nie posiada własnych zakładów produkcyjnych, a ich produkty wykonują setki niezależnych dostawców, kluczowym obszarem CSR są relacje biznesowe w łańcuchu dostaw.

Minimalizowanie ryzyka refutacyjnego, wynikającego z rozbudowanych łańcuchów dostaw, oznacza konieczność prowadzenia zintegrowanych działań w całym łańcuchu dostaw - ustalania norm i standardów działania zorientowanych na wdrażanie koncepcji CSR w biznesie, a następnie kontroli realizacji tych wytycznych w sposób 
niezapowiedziany i przez niezależne podmioty. Kluczową kwestią jest również rozszerzenie omawianej kontroli na dostawców drugiego rzędu i kolejnych.

Współpraca międzynarodowych korporacji z lokalnymi przedsiębiorstwami kraju goszczącego może doprowadzić do redystrybucji umiejętności i wiedzy wśród jej partnerów, również w obszarze CSR. I taka sytuacja ma miejsce na polskim rynku. MŚP, współpracując z zagranicznymi korporacjami, podejmują liczne działania dostosowawcze, które wpływają na ich pozycję konkurencyjną i otwierają nowe możliwości współpracy, również na rynkach zagranicznych.

Z drugiej strony w polskich warunkach relacje między korporacjami a lokalnymi firmami bazują często na przewadze transakcyjnej tych pierwszych; pojawiają się liczne nadużycia zagranicznych podmiotów w stosunku do słabszych ekonomicznie partnerów.

Można jednak przypuszczać, że ta sytuacja powoli będzie się zmieniać. Presja społeczna i polityczna, jak również konieczność zacieśniania relacji z kontrahentami (ze względu na silną konkurencję, dynamikę zmian potrzeb klientów i potrzebę koncentracji na kluczowych obszarach działalności) będzie wymuszać praktyki zorientowane na wzrost zaufania między współpracującymi przedsiębiorstwami (Kłosiewicz-Górecka, 2014).

\section{Literatura \\ References}

Burt, R.S. (2001). Structural Holes versus Network Closure as Social Capita. W: N. Lin, K. Cook, R.S. Burt (red.). Social Capital: Theory and Research. New York: Aldine Transaction.

CSRinfo (2012) (2017, 14 lutego). Jak zyskać na odpowiedzialności? CSR w strategiach spółek giełdowych. Pozyskano z http://seg.org.pl/sites/seg13.message-asp.com/files/jak_zyskac_na_ odpowiedzialnosci_csrinfo.pdf

Ćwik, N. (2011) (2016, 10 czerwca). Wspólna odpowiedzialność. Rola dostaw i zakupów. FOB. Pozyskano z http://odpowiedzialnybiznes.pl/wpcontent/uploads/2014/01/Wspolnaodpowiedzialnosc_rola_dostaw_i_zakupow.pdf

Fundacja Centrum CSR.PL (2013) (2017, 2 czerwca). Brudny zysk. Pozyskano z http://www.centrumcsr.pl/wp- Brudny zysk

Kłosiewicz-Górecka, U. (2014). Nieuczciwe praktyki handlowe w łańcuchu dostaw FMCG. Przemysł Spożywczy, 68.

Kochaniec, A. (2002). Zagraniczne przedsiębiorstwa handlowe w Polsce. W: A. Zorska (red.). Korporacje międzynarodowowe $w$ Polsce. Wyzwania $w$ dobie globalizacji i regionalizacji. Warszawa: Wydawnictwo Difin, 110-135.

Kowalska, K. (2012). Rozwój polskich sieci detalicznych jako sposób ograniczania siły rynkowej międzynarodowych korporacji handlowych. Warszawa: Wydawnictwo Difin.

Makuch, Ł. (2011) (2017, 16 lutego). Normy i standardy społecznej odpowiedzialności biznesu (CSR). Pozyskano z https://obszarcsr.files.wordpress.com/2011/04/standardy_csr.pdf

Meronk, H., Bielewicz, A. (2009). 10 pułapek projektów outsourcingowych. Harvard Business Review, 71, 148-153.

NIK (2002) (2016, 5 kwietnia). Informacja o wynikach kontroli lokalizacji dużych obiektów handlowych (super i hipermarketów). Białystok. Pozyskano z https://bs.sejm.gov.pl/F?func=find-b\&request $=000059034 \&$ find_code=SYS\&local_base=BIS01

PARP (2015) (2016,5 kwietnia). Odpowiedzialnośćsięopłaca, czyli CSR w MŚP.Pozyskano z https:// www.parp.gov.pl/attachments/article/48658/Odpowiedzialnos\%CC\%81c\%CC\%81\%20 sie\%CC\%A8\%20op\%C5\%82aca,\%20czyli\%20CSR\%20w\%20MS\%CC\%81P.pdf

Prahald, C.K., Krishan, M.S. (2008). The New Age of Innowation: Driving Cocreated Value Through Global Networks. Nowy Jork: McGraw-Hill. 
Przybylska, K. (2001). Determinanty zagranicznych inwestycji bezpośrednich $w$ teorii ekonomicznej. Kraków: Wydawnictwo Akademii Ekonomicznej w Krakowie.

Przybylska, K. (2010). Obszary współpracy transnarodowych korporacji z lokalnymi dostawcami kraju goszczącego. W: Wybrane problemy współpracy transnarodowych korporacji z lokalnymi firmami kraju goszczącego. Kraków: Uniwersytet Ekonomiczny, 59-77.

Rojek-Nowosielska, M. (2017). Społeczna odpowiedzialność przedsiębiorstw. Model-diagnozaocena, Wrocław: Wydawnictwo Uniwersytetu Ekonomicznego we Wrocławiu.

Rymarczyk, J. (1996). Internacjonalizacja przedsiębiorstwa. Warszawa: Polskie Wydawnictwo Ekonomiczne.

Sulejewicz, A. (1997). Partnerstwo strategiczne. Modelowanie współpracy przedsiębiorstw. Warszawa: Szkoła Głowna Handlowa.

Szwajca, D. (2016). Zarzq̨dzanie reputacja przedsiębiorstwa. Warszawa: CeDeWu.

Taymaz, E., Kılıcaslan, Y. (2005). Determinants of subcontracting and regional development: An empirical study on Turkish textile and engineering industries. Regional Studies, 39.

Tylec, T. (2010). Transfer technologii z transnarodowych korporacji do lokalnych przedsiębiorstw. W: Wybrane problemy współpracy transnarodowych korporacji z lokalnymi firmami kraju goszczącego. Kraków: Badania statutowe UEK, 97-117.

Katarzyna Kowalska, dr nauk ekonomicznych w dyscyplinie ekonomia (Uniwersytet Ekonomiczny w Krakowie). Zainteresowania naukowe: konkurencyjność przedsiębiorstw, współpraca przedsiębiorstw, strategie rozwoju przedsiębiorstw, zrównoważony łańcuch dostaw, CSR.

Katarzyna Kowalska, Ph.D. in Economics (Cracow University of Economics). Research interests: competitiveness of enterprises, cooperation of enterprises, strategies of enterprise development, sustainable supply chain, CSR.

\section{Adres/address:}

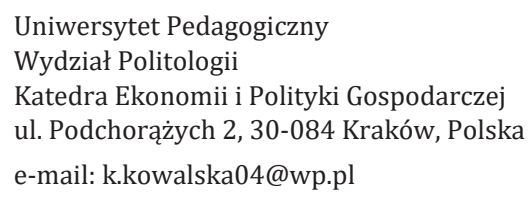

